indeed, therefore, will be the disappointment, if the faithful city should not arouse itself, put forth all its energies, and carry out this necessary hygienic improvement.

There are several other points to which, if there were time, I should allude more fully, but to which I shall now only cursorily direct your notice. It is placed beyond all contradiction that the state of the graveyards within our cities is a frequent source of disease, and Worcester is open to this evil. The difficulties that have opposed themselves to better sanatory arrangements in this respect are great; but let us hope that cemeteries without our cities may gradually become the approved mode of sepulture by all classes of the inhabitants, and we shall then reap the reward in improved public health.

The slaughtering of animals is another evil which calls for a remedy, as does also the keeping of animals, as horses, pigs, dogs, \&c., which a better system of police would render less noxious to the inhabitants.

The clothing and diet of the humbler classes are of much importance. Worcester is not subject to those great ricissitudes to which large manufacturing towns are liable, and consequently the labouring population are not so much sffected by them, their prosperity never being rery great nor their adversity so appalling. A corresponding condition of their food and clothing is the result.

Vegetable food and tea are in great request, and the failure of the potato crop has been a source of difficulty. I shall not, however, here dilate upon this, but I may remark, that the causes producing disease in the regetable kingdom, seem also coincidently to have affected the animal. Epizootics amongst horses and cattle have been observed in many places, and the reports of the Registrar General for 1846 shews an increase in the mortality, so that in fact, whilst we are planning and considering what can be done to diminish the insalubrity of towns, Providence sends a visitation which tells us that all our endeavours without his concurrence are vain. For some years past there was reason to believe that the causes of mortality in towns were less operative. The Registrar General in his report for 1845, says, in the last three years the price of provisions was cheaper, the cominerce and manufactures of the country were more active, the relief to the destitute more liberally administered, and the wages of artisans higher; and all these circumstances favourable to public health undoubtedly contributed to the reduction of the mortality observed. In the midst, however, of all these pleasing prospects, in 1845 and 1846 there is a visitation of a blight in the potatoes and other vegetable productions, - and what is the result? Why in 1846 epidemic disease to a considerable extent prevails in the three kingdoms; the mortality has increased, and in many parts has been one fourth, and one third, and in some in double the amount of former years.

Worcester has been leniently visited, and the epidemic affection has been lighter than in many parts, qut still enough has occurred to show that epidemic risitations will come, and that they fall most heavily where the laws of public health are most neglected.

This, then, is our encouragement. Providence puts within our power certain means of prevention. We know them. They are plain before our eyes. Shall we, then, be indifferent to these things? Is our life so long that we can afford to lose a considerable portion of it by neglect? The future must answer these questions. Hitherto indifference to these matters has been abundantly evident amongst all classes.

I feel that $I$ have occupied more time than the nature of these meetings will well allow, but you will excuse me if I have delayed you too long, when you consider that the subject on which I have been addressing you is one in which, as Christians, and as men, we are all deeply interested; for however great may be the honours of those who by brilliant exploits add to the glory of their country, few will deny, that those deserve well, and contribute to her political welfare, who add to the health and happiness of the poor, who are always the mass of the community. Depend upon it, whatever tends to exalt them in the scale of moral and rational creatures, tends also in the same degree, to exalt the nation, of which they must always form the largest part in political power.

None but those who are in the habit of ningling with the lower classes can have a notion of the intimate connection which exists between physical and moral degradation. From religious motives alone then we may insist upon the necessity of endeavouring to improve the condition of the poor, and we should never weary in our efforts to induce the Legislature to devote their energies to this matter.

\section{THE LAW OF THE MORPHOLOGY OR META-} MORPHOSIS OF THE TEXTURES OF THE HUMAN BODY.

(Fourth Series of Experimental Researches.)

By Williax Addison, M.D., F.R.S., Malvern. (Continued from page 62.)

III. Exbryo and Adult Textures.

The microscopical researches of Dr. MARTin BARRY and others have established the fact, that the first texture of the human embryo and its appendages is corpnescular, or incoherent cellular,-that is to say, a texture composed of cells or corpuscles, which have exceedingly thin walls, are very soft and brittle, having but a slight cohereucy. These cells have many analogies with the cells of the cellular textures of regetables, - with the protoplasma cells of MонL, in preceding all the solid formations, and containing a viscous colourless mass, mixed with granules or molecules, and with the incoherent chlorophylle cells of a leaf, in containing a material essential to the growth of the future and more important parts of the structure, in both cases, the material being a secreted or elaborated one.

When the embryo is growing, the transparent membrane or amnion formed around it is first 
corpuscular, then coherent cellular, and then fibrous; and the walls of the blood-vessels ramifying upon it, undergo the same changes; they are first corpuscular, then cellular, and lastly filrous. This then is the order of the morphology, in respect of the membranous envelopes of the embryo,-viz., first corpuscular, then cellular, and then fibrous. In the embryo itself, a month or five weeks old, and half an inch in length, several textural groups, representing the head, eyes, and extremities, the spinal column, liver, and heart, may be discriminated. All these groups, when examined with the microscope (700 linear,) are found to consist wholly of incoherent cells or corpuscles, soft and easily separable from each other; and they ure all filled with a protoplasma, a viscous colourless matter, mixed with molecules. At this early period, nothing resembling a coherent cellular texture can be found; all is soft, pulpy, and brittle; there are neither blood-vessels nor fibres, nor can anything hard or coherent, resembling cartilage or bone, be detected. When the embryo is four months old and seven inches long, the brain, liver, \&c., are groups of corpuscular texture,-soft, brittle, and incoherent. In the lungs, nothing resembling the adult pleura can be dissected, eren with the utmost care, from their surface; and the thinnest section that can be made, gives (with a microscopic power of 700,) a coherent cellular texture, ningled with the isolated cells of an incoherent texture. The skin, both epidermis and cutis, viewed with a power of eighty diameters, exhibits a great number of small dots or granulations, and so likewise does the pericardium and the other (will-be) fibrous membranes. These granulations, when more higbly magnified (700,) are found to be groups of coherent cellular texture, and the whole texture exhibits the same character. The young hair upon the head is very clearly a coherent cellular texture; the heart is a pass of elongated coherent cells; and it is only in the pericardium and other unalogous strong membranes that waved fibres have yet appeared. The muscular fibrillæ are more advanced, and have their transverse markings; but nothing rese mbling nerve fibres (properly so called,) can be detected, though cells with long projecting tubes, filled with a molecular matter, may be seen mingled with others, especially in the embryo texture of the spinal cord. In the bones of the cranium, the nascent osseous cylinders exhibit small, bony, or hard, cell-like particles, dispersed in a semi-transparent matrix, surrounded and enveloped on all sides in a very vascular fibro-cellular texture.

In the fotus at birth, the soft corpuscular textures have assumed nearly their permanent characteristics; but this is far from being the case either with the fibrous, cartilaginous, or osseous textures, corpaseles or cells being still the most abundant elements in the fibrous textures, and largely ningled with the young thres of the walls of the blood-ressels.
During infancy and youth all the later-formed teztures are undergoing different phases of metamorphosis, until the adult period or permanent form is established. At the adult period the permanent textural form of the grey portion of the brain, of the liver, the intestinal villa, and the plexus choroides, \&c., is corpuscular, - a soft, brittle, tender, and incoherent cellular texture. The parenchyma of the lungs is coherent cellular. The areolar textures, the dura mater, pia mater, pericardium, \&c., fibrous; and, without making special reference to nerve-tubes, and muscular fibrillæ, there are also fibro-cartilaginous, cartilaginous, and osseous textures." But, as all these textures were at first soft, brittle, incoherent, and corpuscular, the permanent form of some textures; then coherent-cellular, the permanent form of other textures; then fibrous, fibro-cellular, and cartilaginous, the permanent forms of others; and then osseous; so therefore it is concluded, that the law of the metamorphosis in the human structure is from soft, semi-fiuid, incoherent, corpuscular textures, to the coherent cel. lular; from these to fibrous, fibro-cellular, and cartilaginous; and lastly to bone.

I am not aware that there is any difference of opinion among physiologists as to the general order in which the textures of the human structure appear, and I presume they are ready to admit that soft and but slightly-coherent cellular or corpuscular groups, precede the coherent cellular textures; that the cellular precede the fibrous and cartilaginous, and the cartilaginous precede bone. They are at least agreed upon the analogous fact in vegetable structure, "cells containing a viscous colourless mass mixed witk granules everywhere," as Монц observes "preceding the first solid formations."

In the human embryo then, the primary metamorphoses, out of which the future textures arise, take place in groups of corpuscular texture, before any circulating blood, or any blood-ressels can be detected; and the singular variety of the metamorphoses, even in a single organ, way be judged of from the structures of the eye. At this early period, it is by investigations with the microscope in the midst of these corpuscular groups, that the primary changes must be sought; but when blood-ressels or rather blood-channels are visible, and there is blood, a cellular or corpuscular fluid circulating through them, it is then along the inner margins of their walls that the nature of the subsequent metamorphoses, - those which establish the form and quality of the adult organs,-must be looked for.

The growth of the textures of the luman embryo prior to the circulation of a current of blood-cells, is

- These are the broad distinguishing types of the textures, but there are many of a mixed character; the pleura is fibro-cellular, and the macous texture of the air tubes is fibro-corpuscular. 
in every respect analogous to the growth of the vegetable embryo prior to the formation of a green leafy parenchyma. And, as in the human structure, the blood current is essential to continued growth and future textures, so likewise in the regetable structure, in the leafy parenchyma, and moreover, as regetable structures are disposed to revert to a leafy parenchyıa, só an analogous disposition will be shown to exist in animal textures.

\section{Structure of Blood-vessels.}

The anatomical or structural elements of the adult blood-vessels, as long as their course lies embedded in a fibro-cellular or areolar texture, and whilst merely transmitting the current of the blood, although varying a little in different places, still uniformly consist of sundry layers of fibrous and fibro-cellular textures, the fiores in some of the layers being enlarged longitudinally, parallel with the course of the vessel, others circularly, passing around the ressel. The fibres are thick and strong, especially the outer layers, in proportion to the size of the ressel, or of the column of blood it conveys; and they inclose in their interstices, and are firmly united with, the nuclei of cells, and with a vast amount of granular and molecular matter, sometimes mingled with globules of oil or fat. In the very small branches of the blood-vessels, those which are on the point of leaving the fibro-cellular texture interposed between the lobular subdivisions of the rarious organs, and which are therefore approaching the scene of the nutritive function, the vascular walls or coats of the ressels are less fibrous; and it is evident from a careful examination, that they more and more partake of forms that are identical with those which constitute $t$ he parenchyma or special texture they supply; until at length in the true nutrient or capillary channels it appears to be impossible to discriminate (certainly it is impossible to observe any practical distinction,) between the elements of the parenchyma and the walls of the ressels. Two textures easily examined, may be instanced in illustration:-In the pia mater the walls of the ressels are fibrous, - a transparent fibrous parenchyma or membrane; in the plexus choroides they are corpuscular, - a corpuscular parenchyma.*

But, as all the various textures, from the beginning in the embryo up to the period of birth, and from birth

- The increasing importance of the elements of the walls of blood-ressels, as the ressels diminish in size, is indicated by the fact, which may be demonstrated in the ressels of a transparent texture, that the thickness of the wall is, as a general rule, inversely proportional to the diameter of the column of blood it conveys. In a large vessel, 1-100th of an inch, the thickness of the coat visible on each side as viewed through the microscope (70), is not more than one third or one fourth the diameter of the colunin of blood; whereas in a small vessel 1-500th or 1.1000 th of an inch, the reverse proportions are frequently seen; the thickness of the wall of the vessel being three or four times greater than the didmeter of the blood-stream. Hence there is no difficalty in clearly seeing the stages of nutrition bereafter pointed out. to puberty, are gradually ascending to their permanent forms, some reaching it soon, others later, so therefore the elements of the walls of the blood-ressels, and particularly those of the nutrient vessels, vary not only in the different organs, but in the same organ, pari passu, with the morphological evolution,-that is to cay, in other words, they vary with the age of the organism, differing in the same place in the infant from the embryo; in the child from the infant; and in the adult from the child.

\section{Structure of the Lungs.}

The air-cells of the lungs are not indiscriminately thrown together in the interior of the organ; on the contrary, they are symmetrical with the branches of the air-tube, and collected or associated in numerous small communities or groups, each group forming what is termed a lobule; many lobules grouped together form a lobe, and five lobes form the two organs called the lungs. A pulmonary lobule is a perfect respiratory organ in itself, the whole lung being but a series of reduplications of the same structure-an aggregate of lobules. At one of the corners or angles of a lobule, a division of the air-tube, and an arterial bloot-vessel enter into its interior, and at the same place a rein comes out, and by these three cylindrical structures the lobule is connected with its fellows. The membrane which forms the walls of the air-cells, constitutes the parenchyma or proper texture of the lungs, and the capillary vessels so densely distributed upon it have no other coats or boundaries than those furnished by this parenchymatous texture. The practical point to be insisted on, with a view to the correct understanding of the pathology and diseases of the lung, is that involving the relation of the walls of the air-cells to the extremities of the air-tube on the one hand, and to the blood-ressels on the other.

The air-tubes and blood-ressels before entering into the interior of the lobules, run in the spaces between them, and here, cushioned as it were upon an areofar texture, they have severally their own distinctive elements and structures; but within the lobules, after sundry subdivisions, they all terminate in, and their textures become continuous with, the walls of the aircells, - that is to say, with the parenchymatous texture; and here it is impossible, even with the microscope, to discriminate between the elements continuous with, or prolonged from, the coats of the blood-ressels and those continuous with, or prolonged from, the air-tubes, -that is to say, in other words, the outer surface of the thin transparent wall of every air-cell is in close relation with the interior of the blood-vessels, and its inner surface is as closely related to the air-tubes.

The parenchyma of the lung is usually described by anatomical writers as a mucous texture,-that is, a secreting texture, but it has none of the anatomical characters of a mucous texture, its perfect transparency and elasticity resemble much more the characters of a 
fibrous or serous texture; moreover, it is well-known that its capillaries have a special function, and no analogy whatever exists between them and the capillaries of a secreting texture. In the adult lung the parenchyma is coherent cellular; the areolar texture interposed betiven the lobules is fibrous and fibro-cellular; the pleura which covers the whole lung, and lines the interior of the cavity of the chest, is both cellular and fibrous,-cellular on its smooth free surface, and fibrous beneath. The mucous texture of the interior of the air-tube is fibro-corpuscular,-that is, composed of fibres intermingled with incolserent cells, and the blood is a corpuscular fluid, flowing in streams over the walls of the coherent cellular parenchyma. But in the embryo all pulmonary textures are composed of soft, and but slightly cohering cells; in the fotus they are partly corpuscular, and partly coherent-cellular; and during infancy and youth the walls of all the nutrient vessels, even of those which have become fibrous, are largely charged with incoherent corpuscles or cells. Hence then, the morphology of the textures of the lung is corpuscular, cellular, and fibrous; and there is nothing, except in the larger branches of the air-tube, of a cartilaginous or osseous texture.

VI. Physiological Axalysis of the Corpuscular, Cellular, and Fibrous Textures.

Keeping in view the distinctions insisted on between the corpuscular and the cellular textures, it is evident that the corpuscular are the secreting textures, and the cellular non-secreting ones, - that is to say, the cells or corpuscles of the secreting textures, with their thin walls and elaborated contents, are teinporary and evanescent e̊lements; while the cells of the coherentcellular textures, with their strong elastic and transparent walls, are comparatively durable and permanent; and as the rapidity of the changes and displacements which the elements of a structure undergo, is in a direct ratio with their importance in the functions of nutrition, secretion, and life, so therefore the cells or corpuscles of the corpuscular textures are more actire or energetic than the cells of the cellular.

Again contrasting the corpuscular with the fibrous textures, the latter perform the comparatively mechanical offices of separating, investing, and limiting in bulk, the different groups of the various corpcscular and cellular textures, engaged in the more active functions of life, transmitting the larger columns of blood to and from them. These functional distinctions are indicated by the anatomical fibrous element, and by the species of rascularity observable in the texture. The corpuscular or secreting textures are everywhere traversed by multitudes of nutrient ressels, specially disposed in different 0.gans; whereas the fibrous nonsecreting ones, although in some instances extremely vascular, in consequence of having to transmit a multitude of small ressels, have yet comparatively few nutrient capillaries, and these variable and irregular in their disposition. The dura mater and pia mater are both fibrous membranes, surrounding, supporting, and protecting in bulk, the whole brain or central organ of the nervous system. The dura mater, as its name I suppose implies, is an exceedingly strong and coherent texture, transmitting immense columns or streams of blood to and from the brain, yet is itself scantily supplied with nutrient capillaries. But the arterial currents traversing the dura mater, and those still larger ones arising from other quarters, before they can be admitted into the soft corpuscular texture of the brain, must be dirided and subdivided many times into the smallest possible streams, and the force of the heart's action subdued by sinuous turns and windings. For these ministerial purposes the much more fine and delicate fibrous texture of the pia mater is interposed, which not only atfords space and area fo: the subdivisions of the blood-current, thereby becoming extremely vascular, but slipping down between all the lobular subdivisions of the organ, (here termed convolutions,) it enters into the recesses, supporting and limiting and conveying vessels, through which the blood reaches and returns from all parts of the soft and tender parenchyma of the great organ of life and being. Lastly, the cellular parenchyma of the laug is not tender, opaque, and brittle, like the corpuscular parenchyma of the liver, but is on the contrary exceedingly coherent, elastic, and transparent, and these anatomical characters indicating, as before observed, that the parenchyma of the lung is not a place of active nutrition or cell-elaboration,-not a secreting texture; and although eminently rascular, more so, perhaps, than any other texture of the body, still the vascularity is analogous to that of the pia mater, a ministerial and not a nutritive vascularity, the analogies of the texture being altogether with the fibrous non-secreting, and not with the corpuscular and secreting textures. This corresponds with facts; the only outlet and inlet to the lungs is by the windpipe; and if the air-cells, which have been computed to number 1.744.000.000 in each lung, or if an expanse of membrane equal in area to 1500 square feet, were a secreting membrane in the ordinary and proper acceptation of the term, persons would be always swallowing, or spitting, or coughing, which we know in health is not the case. The fine transpararent cellular texture of the pulmonary parenchyma aliows the finer and vapourous elements of the blood to transude its walls, but it does not, 1 conceive, in the proper sense of the word, gire rise to a secretion.

(To be continued.) 